\title{
EFFECT OF PRESSURE ON THE QUALITY OF PESTICIDE APPLICATION IN ORCHARDS
}

\author{
Alcides Di Prinzio ${ }^{1}$, Sergio Behmer ${ }^{1 *}$, Jorge Magdalena², and Germán Chersicla ${ }^{1}$
}

\begin{abstract}
Only part of the active ingredient used in agrochemical applications in orchards is retained on the trees. The product that is not retained is lost as sedimentation in the soil and as drift, the latter being a major source of environmental pollution. Unfavorable atmospheric conditions affect the uniformity of distribution and increase product loss. This can be mitigated by the utilization of larger drops. The objective of the present work was to evaluate the effect of service pressure on distribution in the trees and product loss by using a conventional hydro pneumatic sprayer. A fluorescent tracer was applied on fruit trees by an airblast sprayer, with two treatments: high pressure (1800 kPa) and low pressure $(500 \mathrm{kPa})$. Samples were collected from the trees, in columns and from the soil. The results indicated that there were no differences between the two treatments in the total quantity of deposits recovered from leaves. There was one third less drift with the low-pressure than with the high-pressure treatment, whereas deposits on the soil were similar with the two treatments, with the low-pressure treatment presenting a higher concentration of deposits in the proximity of the treated row. In conclusion, the use of sprayer systems that operate with low pressure is a valid alternative to reduce environmental pollution because it tends to loss to the area where the treatment is being applied, without affecting deposits on the trees.
\end{abstract}

Key words: orchards, sprayers, drift, service pressure.

\section{INTRODUCTION}

During the application of agrochemicals only part of the of the active ingredients being used is retained on the trees, depending on the vegetative state, the technique being used and the environmental conditions at the time of application (Baraldi et al., 1993; Doruchowski, 1993; Solanelles et al., 1996). The unretained product is lost as sedimentation in the soil and as drift, becoming a serious source of environmental contamination.

The Environmental Protection Agency of the USA, as cited by Salyani and Cromwell (1992), estimated that between 10 and $60 \%$ of the agrochemicals applied drift to more than $300 \mathrm{~m}$ from the treated area. This is even more relevant in regions with intensive cultivation characterized by a higher density of rural population.

${ }^{1}$ Universidad Nacional del Comahue, Facultad de Ciencias Agrarias, Cinco Saltos, Río Negro, Argentina. *Corresponding author (sbehmer@uncoma.edu.ar).

${ }^{2}$ Instituto Nacional de Tecnología Agropecuaria (INTA), Estación Experimental Agropecuaria Alto Valle, Gral. Roca, Río Negro, Argentina.

Received: 28 December 2008.

Accepted: 19 August 2009.
Vercruysse et al. (1999), upon applying a fungicide in low fruit trees, found deposits up to $40 \mathrm{~m}$ from the application site that, while 20 times as low as deposits found at $5 \mathrm{~m}$, represented between 2.5 and $4.5 \%$ of the volume sprayed. Copes et al. (2006) found residues from an application in fruit orchards up to $48 \mathrm{~m}$ from the treated row. They emphasized that the rural population within this area and beyond is at risk of contamination.

Huijsmans et al. (1994) indicated that air assisted spray systems, while they facilitate transport and penetration of the drops in the interior of the tree canopy, could also increase drift and deposits of chemical product in the soil. They argued that it is necessary to improve application techniques to reduce environmental contamination.

Heijne et al. (2004) described a series of methods and technologies to mitigate drift, such as windbreak barriers, areas free from cultivation, spraying the last row only from the side to the outside of the field, spraying tunnels, reflective screens and foliage sensors. In relation to technological aspects, Di Prinzio et al. (2004) evaluated a spraying tunnel design and found a reduction of drift on the order of $95 \%$ compared to that caused by divergent flow air-blast sprayers. Nevertheless, Cross et al. (2003) affirmed that while sprayers with tangential flow fans and 
spraying tunnels present a substantial reduction in drift, they are not widely used owing to the high cost and/or reduced operational flexibility.

The size and characteristics of the tree are also factors that affect the efficiency of the application. In this sense, Travis et al. (1987) pointed out that the quantity of deposits found on the tree decrease with height and the depth of the canopy, while Magdalena et al. (1996) found, in pear plants trained on trellises at a height of over $4 \mathrm{~m}$, that the quantity of deposits in the upper part of the tree was only $40 \%$ of the quantity found in the lower part.

Holownicki et al. (2004) affirmed that wind affects the uniformity of spray distribution and increases product loss. The authors indicated that this effect could be mitigated with the use of large drops produced by airinduction nozzles.

The influence of service pressure on drop size is well known. In this regard, Musillami (1980) points out that with a reduction of pressure of six times (from 30 to 5 bar), the size of the drops doubles. A similar behavior was cited by Balsari and Airoldi (1993).

With regard to biological efficiency, Frießleben (2004) conducted a series of studies on various crops, including apples, and at different periods of the year. He did not find significant differences in effects using technologies that produce heavier drops compared to those that produce finer drops.

Magdalena et al. (2003) reports that the service pressure used in the Comahue region in the early 1990s was on the order of 30 bar. More recently, as a result of extensive outreach work, it has been reduced to 20 bar. The authors note that the reduction in pressure results in less waste and lower fuel consumption, as well as a better quality of work.

The objective of the present work was to evaluate the effect of service pressure on distribution on the tree and product loss using conventional air-blast sprayers.

\section{MATERIALS AND METHODS}

\section{Site}

The study was conducted at a pear orchard (Pyrus communis L.) cv. Willams, trained on trellises, with $4 \mathrm{~m}$ between rows. The plants had an average height of $4.5 \mathrm{~m}$ and a thickness of $1.7 \mathrm{~m}$. The required application rate was $1800 \mathrm{~L} \mathrm{ha}^{-1}$, calculated according to the TRV method (Cichón and Magdalena, 1992).

\section{Treatments}

High pressure: Pressure $1800 \mathrm{kPa}$, nozzles 6 ATR (flow: $2.75 \mathrm{~L} \mathrm{~min}^{-1}$ ) and 3 ATR (flow: $3.32 \mathrm{~L} \mathrm{~min}^{-1}$ ), arrayed from above on the main arc, application flow:
$53 \mathrm{~L} \mathrm{~min}^{-1}$. Working velocity: 4,54 $\mathrm{km} \mathrm{h}^{-1}$. Application rate: $1750 \mathrm{~L} \mathrm{ha}^{-1}$.

Low pressure: Pressure $500 \mathrm{kPa}$, nozzles 6 ATR (flow: $1.39 \mathrm{~L} \mathrm{~min}^{-1}$ ) and 3 ATR (flow: $1.77 \mathrm{~L} \mathrm{~min}^{-1}$ ), arrayed from above on the main arc and 4 D8 (flow: $3.2 \mathrm{~L} \mathrm{~min}^{-}$ $\left.{ }^{1}\right)$ intercalated in the upper part of the arc located in an additional barral; application flow: $53 \mathrm{~L} \mathrm{~min}^{-1}$. Working velocity: $4.54 \mathrm{~km} \mathrm{~h}^{-1}$. Application rate: $1750 \mathrm{~L} \mathrm{ha}^{-1}$.

The same sprayer was used in both treatments, operating with a fan with a ratio of 3.5:1 and at $470 \mathrm{v}$ $\mathrm{min}^{-1}$ of power takeoff, the air flow supplied on the order of $35000 \mathrm{~m}^{3} \mathrm{~h}^{-1}$, similar to what is required by the orchard used in this assay. For the low-pressure treatment, the left side of the sprayer was used, supplied by the centrifuge pump of the sprayer; while for the high-pressure treatment, the right side of sprayer was used, supplied by a piston, considering that the air velocity of the sprayer is symmetrical for the two sides.

\section{Climatic conditions}

Sampling: $1 \mathrm{~m} \mathrm{~s}^{-1}$; temperature: $16^{\circ} \mathrm{C}$; relative humidity: $50 \%$.

\section{Sampling and evaluation}

Sodium fluorescein $\left(\mathrm{C}_{20} \mathrm{H}_{10} \mathrm{Na}_{2} \mathrm{O}_{5}\right)$ was applied as a tracer, with doses of $80 \mathrm{~g} \mathrm{ha}^{-1}$ (Sigma-Chemical F6377, Steinheim, Germany). Two pairs of pipe cleaners were used to collect drift, located at heights of 2 and $6 \mathrm{~m}$ over four columns $2 \mathrm{~m}$ apart and located behind the second row adjacent to the treated row, along a parallel line $9 \mathrm{~m}$ from the application.

Losses in the soil were collected in Petri dishes and the sampling station consisted of two boxes located on a tray. Eight stations were defined along a line perpendicular to the treated row, located every $2 \mathrm{~m}$, such that they were alternatively under the row and in the middle of the interrow space. The sampling area covered a distance $16 \mathrm{~m}$ from the treated row.

Two samples of 20 leaves each were collected at three heights: $1.5,2.5$ and $3.5 \mathrm{~m}$, to evaluate the distribution on the tree.

The concentrations of deposits in the rinsing water of the collectors (pipe cleaners, Petri dishes and leaves) were determined with a fluorometer (Kontron SFM 25, Milan, Italia).

The surface area of the leaves was determined with a foliar area optical meter (Li-Cor, LI 3100, St. Louis, Nebraska, USA).

\section{Experimental design}

An entirely ramdomized experimental design were performed and three replications of each treatment were 
conducted. An statistical softwarewas used for the ANOVA, andthe Tukey test was used to compare means, with a level of significance of $0.05 \%$.

\section{RESULTS AND DISCUSSION}

\section{Deposits on the tree}

The use of low pressure results in $20 \%$ more deposits on the tree than with high pressure. Nevertheless, the treatments were not statistically different (Table 1).

The low-pressure treatment presented a greater quantity of deposits in the upper part of the tree than the high-pressure treatment (Figure 1). This effect could be related to the number and type of nozzles used in the two treatments. Nevertheless, this behavior tends to solve the lack of uniformity in the distribution on the tree observed by Travis et al. (1987) and Magdalena et al. (1996) in plants with characteristics similar to those used in this assay.

\section{Drift}

The results indicate that there was a lower quantity of product on the columns with the low-pressure treatment, with statistical differences at heights of both $2 \mathrm{~m}$ and $6 \mathrm{~m}$, reducing losses from drift by a third (Table 2). Though not of the same magnitude, this reduction concurs with what was reported by Di Prinzio et al. (2004). The greatest

Table 1. Distribution of sodium fluorescein deposits on the tree.

\begin{tabular}{|c|c|c|c|}
\hline \multirow[b]{2}{*}{ Height } & \multicolumn{3}{|c|}{ Treatments } \\
\hline & $\begin{array}{c}\text { High } \\
\text { pressure }\end{array}$ & $\begin{array}{c}\text { Low } \\
\text { pressure }\end{array}$ & Average \\
\hline & & $\mu \mathrm{g} \mathrm{cm}^{-2}$ & \\
\hline $1 \mathrm{~m}$ & 0.483 & 0.286 & 0.384 \\
\hline $2 \mathrm{~m}$ & 0.370 & 0.542 & 0.456 \\
\hline $3 \mathrm{~m}$ & 0.224 & 0.496 & 0.360 \\
\hline Average & $0.359 \mathrm{Aa}$ & $0.441 \mathrm{Aa}$ & 0.400 \\
\hline
\end{tabular}

difference can be appreciated at a height of $6 \mathrm{~m}$, where the high-pressure treatment generated three times as much drift; which could be attributed to the fact that it generated smaller drops, a behavior cited by Musillami (1980) and Balsari and Airoldi (1993), which would be the most affected by the effect of drift. These results concur with what was reported by Holownicki et al. (2004), who indicated that generating larger drops constitutes a valid method to mitigate drift, although making reference to the use of air-induction nozzles.

\section{Deposits in the soil}

Because the Petri dishes from row 1 and from inter-row 1 were affected by air from the fan during the treatments, they were eliminated from the study.

There were no differences in the average quantity of deposits between the two treatments (Table 3). Likewise, two well-differentiated groups can be appreciated. Row and inter-row 2 presented a higher quantity of deposits than rows and inter-rows 3 and 4; probably because the former could be reached by the remaining product transported by the air from the fan more than by the effect of atmospheric air.

Analyzing the distribution of deposits (Table 3), it can be noted that the low-pressure treatment resulted in a higher quantity of loss than the high-pressure treatment

Table 2. Assessment of agrochemical drift according to sodium fluorescein deposits in columns located at 2 and $6 \mathrm{~m}$.

\begin{tabular}{lcc}
\hline & \multicolumn{2}{c}{ Treatments } \\
\cline { 2 - 3 } Height & $\begin{array}{c}\text { High } \\
\text { pressure }\end{array}$ & $\begin{array}{c}\text { Low } \\
\text { pressure }\end{array}$ \\
\cline { 2 - 3 } $2 \mathrm{~m}$ & $0.097 \mathrm{~A}$ & $0.054 \mathrm{~B}$ \\
\cline { 2 - 3 } Average & $0.254 \mathrm{~A}$ & $0.072 \mathrm{~B}$ \\
\hline
\end{tabular}

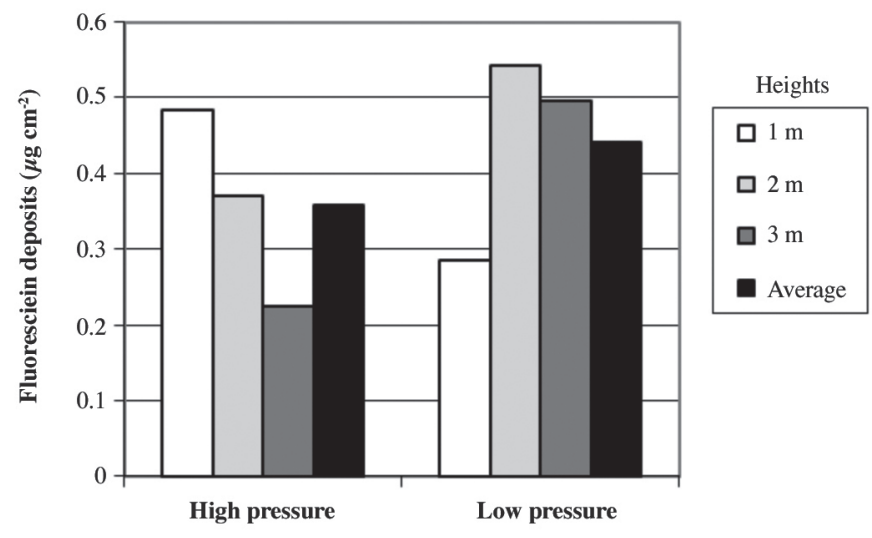

Figure 1. Distribution of sodium fluorescein deposits in the tree. 
Table 3. Assessment of agrochemical loss in the soil according to sodium fluorescein deposits in Petri dishes.

\begin{tabular}{llcc}
\hline & \multicolumn{3}{c}{ Treatments } \\
\cline { 2 - 4 } Position & $\begin{array}{c}\text { High } \\
\text { pressure }\end{array}$ & $\begin{array}{c}\text { Low } \\
\text { pressure }\end{array}$ & Average \\
\cline { 2 - 4 } & \multicolumn{3}{c}{$\mu \mathrm{g} \mathrm{cm}^{-2}$} \\
Row 2 & 0.0388 & 0.0468 & $0.0428 \mathrm{~A}$ \\
Inter-row 2 & 0.0226 & 0.0341 & $0.0284 \mathrm{~A}$ \\
Row 3 & 0.0050 & 0.0013 & $0.0032 \mathrm{~B}$ \\
Inter-row 3 & 0.0059 & 0.0011 & $0.0035 \mathrm{~B}$ \\
Row 4 & 0.0026 & 0.0006 & $0.0016 \mathrm{~B}$ \\
Inter-row 4 & 0.0025 & 0.0005 & $0.0015 \mathrm{~B}$ \\
Average & $0.0129 \mathrm{Aa}$ & $0.0141 \mathrm{Aa}$ & \\
\hline
\end{tabular}

in row and inter-row 2, with the reverse in the other rows and inter-rows. This behavior could be because the lowpressure treatment generates larger drops, which are deposited in the proximity of the treated area, while the drops generated by the high-pressure treatment are more affected by drag from the air current of the fan. This particularity of the low-pressure treatment is very relevant in relation to the objective of reducing contamination of the soil in treated, counteracting the situation proposed by Vercruysse et al. (1999) and Copes et al. (2006).

In summary, although the low-pressure treatment had four additional incalated high-flow nozzles in the upper part of the sprayer arc, which contributes to a better distribution at the risk of increasing loses over the trees. This treatment presented a favorable behavior in relation to decreasing drift, which corresponds to what was affirmed by Holownicki et al. (2004). Taking into account what was reported by Magdalena et al. (2003) and by Frießleben (2004), the low-pressure treatment could be considered more efficient given that aspects related to control and lower energy requirement are added to the possibility of using a larger number of nozzles and orient the to favor a better distribution on the tree, without significantly contributing to product loss through drift.

Nevertheless, more studies would be appropriate to evaluate the influence of drop size and of differential deposits on the upper and lower leaf surfaces, which is expected because of the behavior of larger drops, on efficiency in controlling pests and diseases in fruit trees.

\section{CONCLUSIONS}

The use of spray systems that operate with low pressure is a valid alternative to reduce environmental contamination, given that they tend to limit losses to the area where the treatment is conducted, without affecting the quantity of deposits on the tree.

\section{RESUMEN}

Efecto de la presión sobre la calidad de aplicación de agroquímicos en huertos frutales. Durante la aplicación de agroquímicos se retiene sobre los árboles sólo una parte del ingrediente activo utilizado. El producto no retenido se pierde como sedimentación en el suelo y como deriva, constituyéndose esta última en la mayor causa potencial de contaminación ambiental. Las condiciones atmosféricas desfavorables afectan la uniformidad de la distribución e incrementan las pérdidas de producto; éstas pueden ser mitigadas con la utilización de gotas de mayor tamaño. El objetivo del presente trabajo fue evaluar el efecto de la presión de servicio sobre la distribución en el árbol y las pérdidas de producto utilizando un pulverizador hidroneumático convencional. Se aplicó fluoresceína sobre frutales conducidos en espalderas con un pulverizador hidroneumático, en dos tratamientos: alta presión $(1800 \mathrm{kPa})$ y baja presión $(500 \mathrm{kPa})$ y se recolectaron muestras en los árboles, en columnas, y en el suelo. No hubo diferencias en la cantidad total de depósitos recuperados sobre las hojas de los árboles entre ambos tratamientos. La deriva fue tres veces menor en el tratamiento de baja presión, mientras que los depósitos en el suelo fueron similares entre tratamientos presentando el tratamiento de baja presión una mayor concentración de los depósitos en la proximidad de la fila tratada. La utilización de sistemas de pulverización que operen con baja presión se constituye en una alternativa válida para reducir la contaminación del ambiente ya que tiende a delimitar el alcance de las pérdidas al área donde se realiza el tratamiento, sin afectar la cantidad de depósitos sobre el árbol.

Palabras clave: fruticultura, pulverizaciones, deriva, presión de servicio.

\section{LITERATURE CITED}

Balsari, P., e G. Airoldi. 1993. Macchine per la distribuzione dei fitofarmaci e per il controllo delle malerbe nelle colture erbacee. 153 p. Ed. SAVE.

Baraldi, G., S. Bovolenta, F. Pezzi, and V. Rondelli. 1993. Air, assisted sprayers for orchard and vineyard: First results. p. 265 -272. In Symposium International sur les Techniques D'application des Produits Phytosanitaires [International Symposium on Pesticides Application Techniques], Strasbourg, France. 22-24 September 1993. Vol. 1. Association Nationale de Protection des Plantes, Paris, (France); British Crop Protection Council (Royaume Uni), Paris, France. 
Cichón, L., y J.C. Magdalena. 1992. Avances en la determinación de los volúmenes apropiados a pulverizar en los distintos montes de manzanos en el Alto Valle de Río Negro y Neuquén. Rivista di Agricoltura Subtropicale e Tropicale. Istituto Agronómico per L'oltramare 86(2):357-362.

Copes, W., A. Di Prinzio, S. Behmer, y G. Striebeck. 2006. Contaminación del aire por deriva de pulverizaciones. 118 p. In XXIX Congreso Argentino de Horticultura, Catamarca. 20-23 de Septiembre 2006. Asociación Argentina de Horticultura (ASAHO), La Consulta, Mendoza, Argentina.

Cross, J.V., P.J. Walklate, R.A. Murray, and G.M. Richardson. 2003. Spray deposits and losses in different sized apple trees from an axial fan orchard sprayer. 3. Effects of air volumetric flow rate. Crop Prot. 22:381-394.

Di Prinzio, A., S. Behmer, J. Magdalena, y G. Striebeck. 2004. Evaluación comparativa de dos técnicas de aplicación de agroquímicos en manzanos de alta densidad. Agro-Ciencia 20(2):73-83.

Doruchowski, G. 1993. Use of tunnel sprayers in orchards and berry plantations. p. 281-288. Symposium International sur les Techniques D'application des Produits Phytosanitaires [International Symposium on Pesticides Application Techniques], Strasbourg, France. 22-24 September. Vol. 1. Association Nationale de Protection des Plantes, Paris, (France); British Crop Protection Council (Royaume Uni), Paris, France.

Frießleben, R. 2004. Balancing drift management with biological performance and efficacy. p. 72-79. International Conference on Pesticide Application for Drift Management, Waikoloa, Hawaii. Washington State University, Pullman, Washington, USA.

Heijne, B., M. Wenneker, and J. Van de Zande. 2004. Accepted spray drift reduction methods in fruit growing in the Netherlands. p. 53. Proceedings of International Conference: Environmentally Friendly Spray Application Techniques, Warsaw, Poland. 4-6 October. Research Institute of Pomology and Floricultura, EU Research Centre of Excellence in Sustainable Pomology, Skierniewice, Poland.

Holownicki, R., G. Doruchowscki, W. Swiechowski, and A. Godyn. 2004. Influence of nozzle type and wind velocity on spray distribution within the tree canopy. p. 85-86. Proceedings of International Conference: Environmentally Friendly Spray Application Techniques, Warsaw, Poland. 4-6 October. Research Institute of Pomology and Floricultura, EU Research Centre of Excellence in Sustainable Pomology, Skierniewice, Poland.
Huijsmans, J.F.M., H.A.J. Porskamp, and B. Heijne. 1994. Orchard tunnel sprayers with reduced emission to the environment. Results of deposition and emission of new types of orchard sprayers. p. 297-304. Symposium International sur les Techniques D'application des Produits Phytosanitaires [International Symposium on Ppesticides Application Techniques], Strasbourg, France. 22-24 September. Vol. 1. Association Nationale de Protection des Plantes, Paris, (France); British Crop Protection Council (Royaume Uni), Paris, France.

Magdalena, J.C., A.P. Di Prinzio, C.D. Ayala, y A. Veronessi. 1996. Efecto de la variación del flujo de aire sobre la uniformidad de depósitos de cobre en perales (Pyrus comunnis) conducidos en espaldera. I Congreso Internacional de Ingeniería Agrícola. AgroCiencia Número Extraordinario Julio. p. 21.

Magdalena, J.C., J.C. Gentile, y A.P. Di Prinzio. 2003. Servicio de calibración de pulverizadores frutícolas en Río Negro y Neuquén - período 1990-2001. VII Congreso Argentino de Ingeniería Rural. Mayo 2003.Unidad Integrada EEA Balcarce, INTA-FCA, Universidad Nacional de Mar del Plata, Balcarce, Buenos Aires.

Musillami, S. 1980. Les traitements par pulverisation et les pulvérisateurs en agriculture. CEMAGREF, Montpellier. France.

Salyani, M., and R.P. Cromwell. 1992. Spray drift from ground and aerial applications. Trans. ASAE 35:11131120 .

Solanelles, F., A. Fillat, C. Pifarré, and S. Planas. 1996 A method of drift measurement for spray applications in tree crops. International Conference on Agricultural Engineering. AgEng96 - Madrid (1996), Paper 96-A133.

Travis, J.W., W.A. Skroch, and T.B. Sutton. 1987. Effect of canopy density on pesticide deposition and distribution in apple trees. Plant Dis. 71:613-615.

Vercruysse, F., W. Steurbaut, S. Drieghe, and W. Dejonckheere. 1999. Off target ground deposits from spraying a semi-dwarf orchard. Crop Prot. 18:565570 . 